\title{
Breast metastasis of gastric signet-ring cell carcinoma: a case report and literature review
}

\author{
Chun-Lan He${ }^{1}$, Ping Chen ${ }^{2 *}$, Bing-Lan Xia ${ }^{3}$, Qin Xiao ${ }^{4}$ and Feng-Lin Cai ${ }^{1}$
}

\begin{abstract}
Background: Cases of primary gastric adenocarcinoma with metastasis to the breast are extremely rare. Till now, only 38 cases have been reported in PubMed since 1908.

Case presentation: We herein reported a race case of gastric adenocarcinoma with metastasis to the right breast. Breast biopsy showed invasive signet-ring cell breast carcinoma in the right breast. She was given a TEC regimen (docetaxel $75 \mathrm{mg} / \mathrm{m}^{2}$, epirubicin $75 \mathrm{mg} / \mathrm{m}^{2}$, and cyclophosphamide $600 \mathrm{mg} / \mathrm{m}^{2}$ every 3 weeks) for one cycle but showed no objective response. Upper gastrointestinal endoscopy demonstrated an ulcerative mass in the gastric body. Biopsy demonstrated low-grade gastric adenocarcinoma with signet-ring features. In immunohistochemistry, mammary malignant cells were positive for cytokeratin 7, cytokeratin 20, villin, and ErbB2/HER2, but negative for gross cystic disease fluid protein-15, estrogen receptor, and progesterone receptor. The diagnosis of metastatic poorly differentiated signet-ring cell adenocarcinoma of the right breast identical to gastric primary was confirmed finally.
\end{abstract}

Conclusions: Gastric cancer with metastasis to the breast can be diagnosed by clinical history, histological findings, and immunohistochemical markers.

Keywords: Mammary carcinoma, Metastasis, Gastric adenocarcinoma, Signet-ring cell, Immunohistochemistry

\section{Background}

Gastric carcinoma with metastasis to the breast is extremely rare. Only 38 cases have been reported in PubMed thus far. The lymph node dissemination might be the possible mechanism of metastasis from the stomach to the breast. Sometimes, a metastatic tumor in an occult site may be difficult to be distinguished between a synchronous or metachronous primary cancer and a metastatic disease, especially when it is asymptomatic. In this study, we reported a case of a 48-year-old Chinese woman with a metastasis to the right breast from a gastric signet-ring cell carcinoma and reviewed the literature.

\section{Case presentation}

A 48-year-old Chinese woman was admitted to the Subei People's Hospital of Jiangsu Province, China, on 29 July

\footnotetext{
* Correspondence: chen86ky@126.com

${ }^{2}$ Department of Gastrointestinal Surgery, Subei People's Hospital, Yangzhou University, No. 98 Nantong West Road, Yangzhou 225001, Jiangsu Province, China

Full list of author information is available at the end of the article
}

2014. She complained of a lump in the right breast. Physical examination showed an $8.0-\mathrm{cm} \times 5.0-\mathrm{cm}$ mass lying in the upper inner quadrant of the right breast with axillary lymphadenopathy on both sides. The ultrasound showed an $8.9-\mathrm{cm} \times 4.7-\mathrm{cm}$ ill-defined lesion in the upper inner quadrant of the right breast and a $1.8-\mathrm{cm} \times 1.2-\mathrm{cm}$ enlarged lymph node in the right axilla (Figure 1A,B). Core needle biopsy showed invasive signet-ring cell breast carcinoma (Figure 2A). Immunohistochemistry (IHC) showed that tumor cells were positive for epidermal growth factor receptor (EGFR) and ErbB2/HER2, but negative for estrogen receptor (ER) and progesterone receptor (PR). Serum tumor markers including carcinoembryonic antigen (CEA), cancer antigen (CA) 153, CA125, and CA199 did not elevate. A TEC regimen (docetaxel $75 \mathrm{mg} / \mathrm{m}^{2}$, epirubicin $75 \mathrm{mg} / \mathrm{m}^{2}$, and cyclophosphamide $600 \mathrm{mg} /$ $\mathrm{m}^{2}$ every 3 weeks) was administered as neoadjuvant chemotherapy.

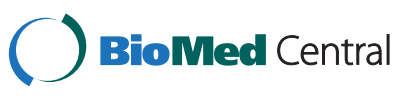




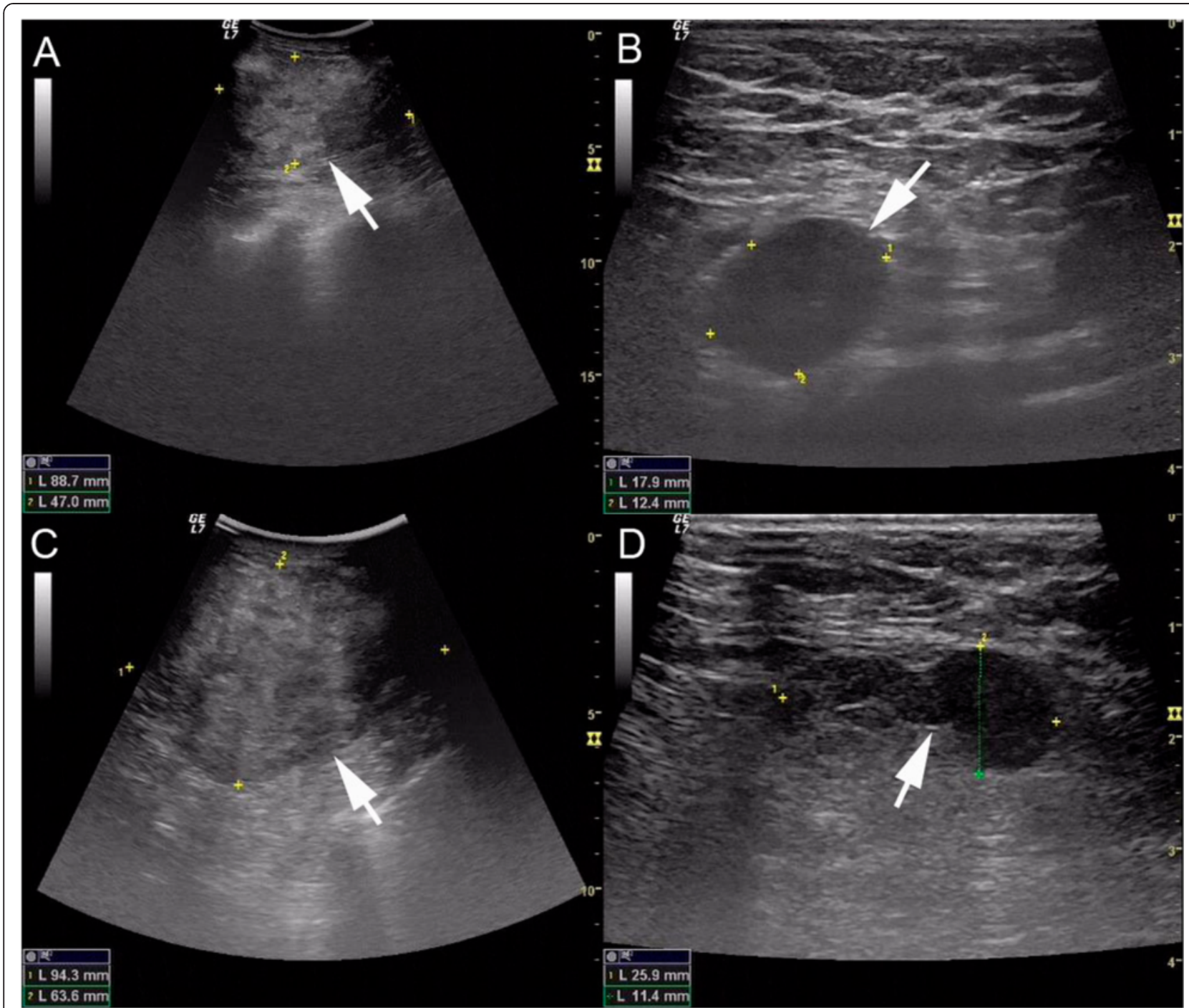

Figure 1 Ultrasonography of the breast. In 30 July 2014, ultrasonography revealed an 88.7-mm $\times 47.0$-mm ill-defined heterogeneity lesion (arrow) in the upper inner quadrant of the right breast (A) with right enlarged axillary lymph nodes (arrow), $17.9 \mathrm{~mm} \times 12.4 \mathrm{~mm}$ in diameter (B). In 21 August 2014, ultrasonography revealed a 94.3- $\mathrm{mm} \times 63.6-\mathrm{mm}$ ill-defined heterogeneity lesion (arrow) in the upper inner quadrant of the right breast (C) with right enlarged axillary lymph nodes (arrow), $25.9 \mathrm{~mm} \times 11.4 \mathrm{~mm}$ in diameter (D).

Because of less response to chemotherapy, ultrasonography was performed and showed an increased $9.4-\mathrm{cm} \times$ 6.4-cm ill-defined hypoechoic mass in the upper inner quadrant as well as a $2.6-\mathrm{cm} \times 1.1-\mathrm{cm}$ enlarged lymph node in the right axilla on 21 August 2014 (Figure 1C,D). Enhanced abdominal computed tomography (CT) revealed a circumferential mural thickening of the gastric body wall (Figure 3C). Upper gastrointestinal endoscopy demonstrated an ulcerative mass in the gastric body (Figure 3A,B). Biopsy of the lesion revealed infiltration from a diffuse-type low-grade gastric adenocarcinoma with signet-ring features (Figure 2B). Serum tumor markers including CEA, CA153, CA125, and CA199 were measured, and only CA199 was highly elevated (more than $1000 \mathrm{IU} / \mathrm{mL}$ ). Further immunohistochemistry showed the tumor was positive for cytokeratin 7 (CK7), CK20, villin, and ErbB2/HER2, but negative for gross cystic disease fluid protein-15 (GCDFP-15), ER, and PR (Figure 2C,D,E, F,G,H,I and Table 1). These features helped to make the diagnosis of primary gastric adenocarcinoma with metastasis to the right breast. Then, the patient was treated with SOX regimen for four cycles (S-1 $80 \mathrm{mg} / \mathrm{m}^{2}$, oxaliplatin $100 \mathrm{mg} / \mathrm{m}^{2}$ ). At time of submission of our manuscript, the patient responded well to the adjusted chemotherapy and was followed for 4 months after the definite diagnosis was made. 


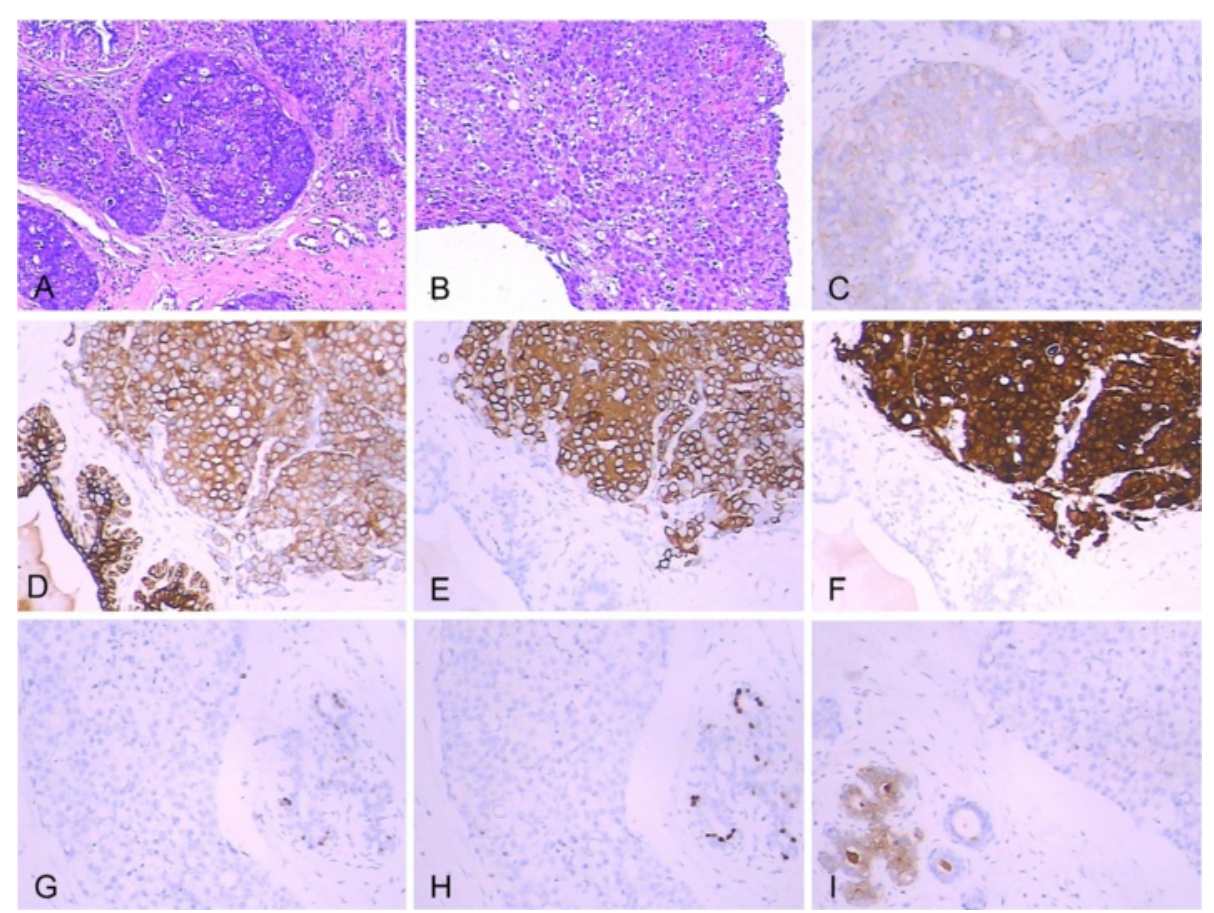

Figure 2 Breast and gastric biopsy and immunohistochemical analysis. Breast biopsy showed invasive carcinoma with signet-ring cells (hematoxylin and eosin, magnification $\times 100)(\mathbf{A})$. Gastric biopsy showed infiltration from a diffuse-type low-grade gastric adenocarcinoma with signet-ring features (hematoxylin and eosin, magnification $\times 100)(\mathbf{B})$. Immunohistochemical analysis revealed mammary tumor cells were positive for ErbB2/HER2 (C), CK7 (D), CK20 (E), and villin (F), but negative for ER (G), PR (H), and GCDFP-15 (I) (3,3'-diaminobenzidine, magnification $\times 100$ ).

\section{Discussion}

Metastases from extra-mammary malignant neoplasms are rare, constituting only $0.5 \%$ to $2.0 \%$ of all mammary malignancies [1]. Malignant melanoma, lymphoma, lung cancer, ovarian cancer, and soft tissue sarcoma have been reported as the most common original tumor of mammary metastases. Gastrointestinal and genitourinary tumors are less common primary sites. Sporadic cases of mammary metastasis have been reported from osteosarcoma, thyroid neoplasm, and cervical, vaginal, and endometrial carcinoma [2-6].

Since primary gastric adenocarcinoma with metastasis to the breast is extremely rare, PubMed, MEDLINE, Embase, and Google Scholar were searched till September 2014 using the key words such as "gastric or stomach"; "tumor or cancer or carcinoma or adenocarcinoma"; "breast or mammary"; and "metastasis." Only 38 cases have been reported previously. We made a summary of all these 38 cases as well as the present case to highlight their clinicopathological characteristics (Table 2). The age of these patients ranged from 23 to 70 years (mean 46.5 years; median 46 years). Among 36 cases, 22 harbored a histological feature of signet-ring cell adenocarcinoma. Moreover, multiple metastases could be found in these cases except the breast.

Metastatic mammary carcinoma is usually correlated with a poor prognosis. Based on the previous reported cases, the overall survival lasted from 12 days to 18 months. In the metastatic process, mammary involvement could either be the first station or occur in a polymetastatic context [7]. Although the pathway by which malignancies metastasized to the breast remains unknown, Vergier et al. [8] hypothesized that estrogen may play a role in promoting extra-mammary tumorigenesis. Also, abundant blood supply of the breast has been proposed as the mechanism for the increased incidence of breast metastasis in premenopausal women. On the other hand, the metastases from gastric carcinoma to the breast had a surprisingly unified tendency. The left breast involved accounted for $55.9 \%$ (19/34) of all cases, while the right side accounted for 23.5\% (8/34) and both sides 20.6\% (7/34). Accordingly, Parrell et al. [9] reported that breast metastases were most commonly found in the upper outer quadrant of the left side. This phenomenon suggested the left supraclavicular lymph node might be important in the process of metastasis from gastric carcinoma to the breast. Occult 


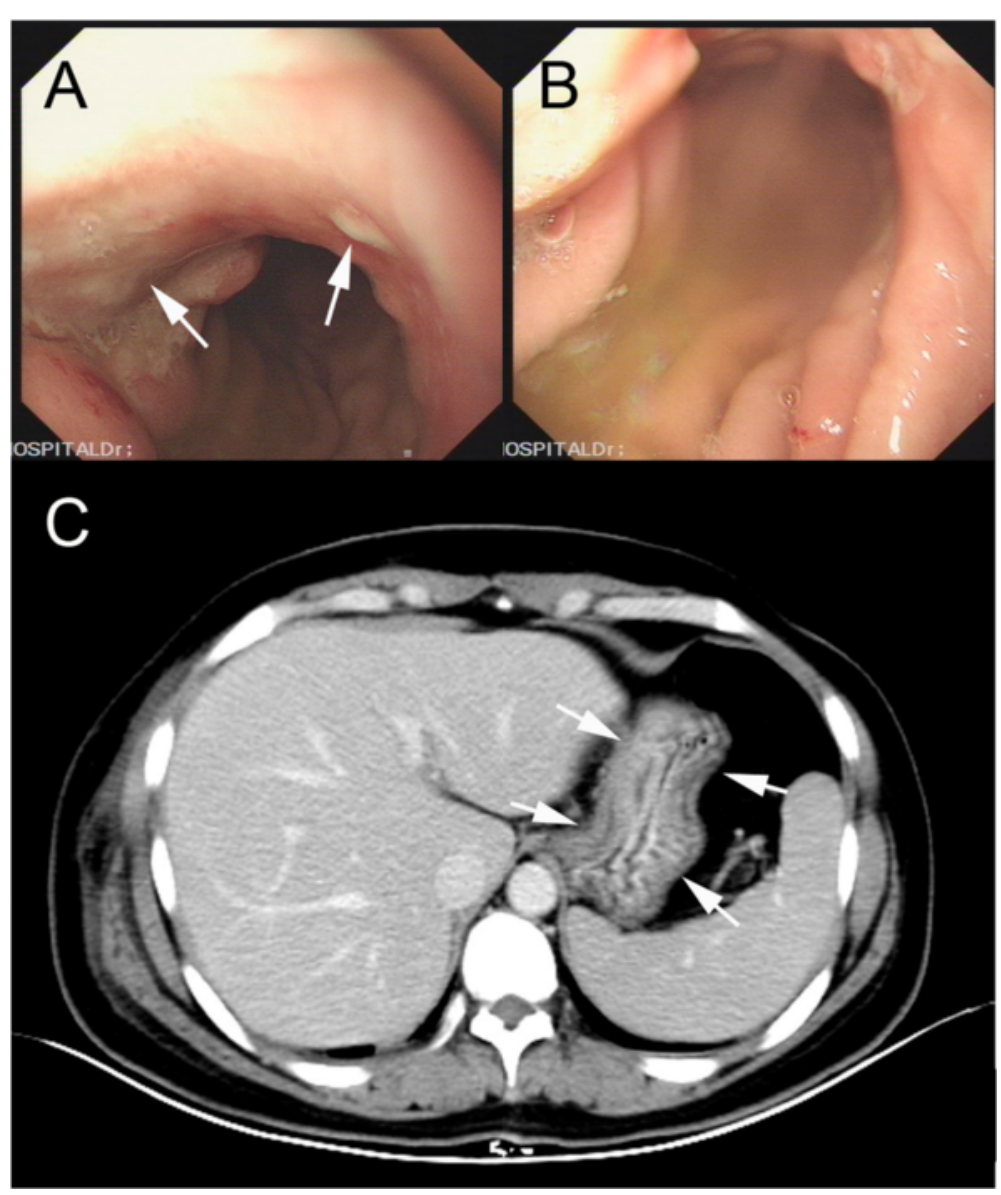

Figure 3 Gastric endoscopy and enhanced abdominal CT scan. Gastric endoscopy showed an ulcerative mass in the gastric body (arrows) (A,B). Enhanced abdominal CT scan revealed a circumferential mural thickening of the gastric body wall (arrows) (C).

adenocarcinoma often poses a challenge to clinicians and pathologists and may lead to an absolutely different therapeutic strategy. Histopathology is useful to differentiate mammary metastasis from primary breast cancer [10]. IHC remains the main choice in identifying

\section{Table 1 Immunohistochemical analysis of mammary} tumor cells

\begin{tabular}{llll}
\hline Antibodies & P/N & Antibodies & P/N \\
\hline CK7 & + & GST-П & ++ \\
CK20 & + & Ki-67 labeling index & $60 \%$ \\
EGFR & + & PR & - \\
ER & - & P-gp & - \\
ErbB2/HER-2 & + & TOPO-II & ++ \\
GCDFP-15 & - & Villin & + \\
\hline
\end{tabular}

P/N: positive/negative; CK: cytokeratin; EGFR: epidermal growth factor receptor; ER: estrogen receptor; ErbB2/HER-2: human epidermal growth factor receptor 2; GCDFP-15: gross cystic disease fluid protein-15; GST-П: glutathione $\mathrm{S}$ transferases $\Pi$; PR: progesterone receptor; P-gp: P-glycoprotein; TOPO-II: topoisomerase II; -: no cells positive by $\mathrm{IHC}$; \pm : sometimes weak positive, sometimes negative by $\mathrm{IHC} ;+:<25 \%$ of cells positive by $\mathrm{IHC} ;++: 25 \%-50 \%$ of cells positive by $\mathrm{IHC} ;+++:>50 \%$ of cells positive by $\mathrm{IHC}$. the tumor origin. Although only few of tumor markers are very specific with limited sensitivity, they can be used as a panel to improve the sensitivity. IHC staining for breast metastasis from gastric cancer is usually negative for ErbB-2, ER, PR, and GCDFP-15, but positive for epithelial markers like CEA, CK7, and CK20 [11-13].

\section{Conclusions}

A primary gastric adenocarcinoma with metastasis to the breast is an extremely rare malignancy and is usually associated with poor prognosis. Clinical history, histological findings, and immunohistochemical markers such as CK20, CK7, CDX-2, villin, and GCDFP-15 are helpful in distinguishing primary breast cancer from breast metastasis of gastric cancer.

\section{Consent}

Written informed consent was obtained from the patient. 
Table 2 Clinicopathological features of reported cases of primary gastric carcinoma with breast metastasis

\begin{tabular}{|c|c|c|c|c|c|c|}
\hline Case [ref] & Age & Side & Differentiation & Interval (mo) & Other metastases & Follow-up (mo) \\
\hline Reitmann et al. $1908^{\mathrm{a}}$ & 33 & $R+L$ & Scirrhous & - & - & - \\
\hline Kreibich et al. $1909^{a}$ & 65 & $\mathrm{R}$ & Scirrhous & - & Skin & - \\
\hline Mourier et al. $1910^{\mathrm{a}}$ & 31 & $\mathrm{~L}$ & Mucinous & - & Liver and pancreas & - \\
\hline Stahr et al. $1922^{\mathrm{a}}$ & 46 & $R+L$ & Anaplastic & - & - & - \\
\hline Dawson et al. $1936^{a}$ & 25 & $R+L$ & Mucinous & - & Ovaries & - \\
\hline Abrams et al. $1949^{a}$ & - & - & - & - & - & - \\
\hline Sandison et al. $1959^{a}$ & 56 & L & Signet-ring cell & - & - & - \\
\hline [14] & 59 & $R+L$ & - & 4 & Axillary lymphadenopathy & 6 \\
\hline Hajdu et al. $1972^{\mathrm{a}}$ & - & $L$ & Adenocarcinoma & - & - & - \\
\hline Silverman et al. 1974 [15] & - & - & Mucin-producing & 0 & - & - \\
\hline Toombs et al. $1977^{a}$ & - & - & - & - & - & - \\
\hline Satake et al. $1980^{\mathrm{a}}$ & 39 & L & Signet-ring cell & 0 & - & - \\
\hline Togo et al. $1980^{a}$ & 70 & L & Signet-ring cell & 0 & - & - \\
\hline Nielsen et al. $1981^{a}$ & 59 & L & Mucinous & 0 & - & - \\
\hline Champault et al. $1982^{\mathrm{a}}$ & 65 & L & Adenocarcinoma & 0 & - & - \\
\hline [16] & 46 & L & Signet-ring cell & 0 & Axillary lymphadenopathy & 12 days \\
\hline Kasuga et al. $1986^{\mathrm{a}}$ & 48 & $R+L$ & Signet-ring cell & 31 & - & - \\
\hline [17] & 28 & $R+L$ & Mucinous differentiation & 0 & Lymph nodes & - \\
\hline [18] & 31 & $\mathrm{R}$ & Signet-ring cell & 0 & Lymph nodes, ovaries & - \\
\hline [19] & 36 & L & Poorly with signet-ring cells & 72 & Axillary lymphadenopathy & 3 \\
\hline [20] & - & - & Signet-ring cell & - & - & - \\
\hline Domanski et al. 1996 [21] & 48 & L & Signet-ring cell & 0 & Left supraclavicular nodes & - \\
\hline de la Cruz Mera et al. 1998 [22] & 61 & L & Signet-ring cell & 13 & Pleura & - \\
\hline [23] & 46 & $R+L$ & Signet-ring cell & 2 & Bilateral axillary nodes & - \\
\hline [24] & 41 & L & Signet-ring cell & 0 & Ovaries & - \\
\hline [24] & 23 & $\mathrm{R}$ & Signet-ring cell & 0 & Axillary nodes & - \\
\hline Madan et al. 2002 [10] & 39 & $\mathrm{R}$ & Signet-ring cell & 3 & Ovaries, peritoneum & - \\
\hline [25] & 39 & $R+L$ & Signet-ring cell & 1 & Ovaries, peritoneum, skin & - \\
\hline Boutis et al. 2005 [12] & 37 & L & Signet-ring cell & 0 & Ovaries & 6 \\
\hline [26] & 37 & L & Poorly & 0 & - & 6 \\
\hline [27] & 61 & $\mathrm{R}$ & Poorly & 48 & Peritoneum & 2 \\
\hline Makni et al. 2007 [7] & 40 & $\mathrm{R}$ & Signet-ring cell & 4 & Ovaries, spleen & 18 \\
\hline [11] & 67 & L & Poorly with signet-ring cells & 5 & Left axillary and supraclavicular nodes & 4 \\
\hline Cil et al. 2009 [28] & 63 & L & Signet-ring cell & 12 & Left axillary nodes & 4 \\
\hline Cil et al. 2009 [28] & 65 & L & Signet-ring cell & 24 & Right ovarian, liver and lung & 6 \\
\hline Soler et al. 2010 [9] & 37 & L & Signet-ring cell & 2 & Ovarian & 7 \\
\hline [29] & 37 & L & Signet-ring cell & 31 & - & - \\
\hline [30] & 54 & $\mathrm{R}$ & Signet-ring cell & 0 & Right ovarian & 11 \\
\hline This case & 48 & $\mathrm{R}$ & Signet-ring cell & 0 & Right axillary nodes & 2 alive \\
\hline
\end{tabular}

${ }^{a}$ References are included in [18]. Interval: the time between the diagnosis of gastric carcinoma and the development of metastasis to the breast; mo, month; Poorly: poorly differentiated adenocarcinoma; Signet-ring cell: signet-ring cell carcinoma. 


\section{Competing interests}

The authors declare that they have no competing interests.

\section{Authors' contributions}

C-LH performed the majority of this study and drafted the manuscript. PC, $B-L X, Q X$, and F-LC provided the collection of material from the database. All authors read and approved the final manuscript.

\section{Author details}

'Department of Thyroid and Breast Surgery, Subei People's Hospital, Yangzhou University, No. 98 Nantong West Road, Yangzhou 225001, Jiangsu Province, China. 'Department of Gastrointestinal Surgery, Subei People's Hospital, Yangzhou University, No. 98 Nantong West Road, Yangzhou 225001, Jiangsu Province, China. ${ }^{3}$ Department of Ultrasonography, Subei People's Hospital, Yangzhou University, No. 98 Nantong West Road, Yangzhou 225001, Jiangsu Province, China. ${ }^{4}$ Department of Pathology, Subei People's Hospital, Yangzhou University, No. 98 Nantong West Road, Yangzhou 225001, Jiangsu Province, China.

Received: 3 December 2014 Accepted: 7 March 2015

Published online: 26 March 2015

\section{References}

1. Feder JM, de Paredes ES, Hogge JP, Wilken JJ. Unusual breast lesions: radiologic-pathologic correlation. Radiographics 1999, 19Spec No:S11-26; quiz S260.

2. Akcay MN. Metastatic disease in the breast. Breast. 2002;11:526-8.

3. Alva S, Shetty-Alva N. An update of tumor metastasis to the breast data. Arch Surg. 1999;134:450.

4. Cangiarella J, Symmans WF, Cohen JM, Goldenberg A, Shapiro RL, Waisman J. Malignant melanoma metastatic to the breast: a report of seven cases diagnosed by fine-needle aspiration cytology. Cancer. 1998;84:160-2.

5. Georgiannos SN, Chin J, Goode AW, Sheaff M. Secondary neoplasms of the breast: a survey of the 20th Century. Cancer. 2001;92:2259-66.

6. Yeh CN, Lin CH, Chen MF. Clinical and ultrasonographic characteristics of breast metastases from extramammary malignancies. Am Surg. 2004;70:287-90.

7. Krichen Makni S, Abbes K, Khanfir A, Frikha M, Sellami Boudawara T. Metastatic signet ring cell carcinoma to the breast from stomach. Cancer Radiother. 2007;11:276-9.

8. Vergier B, Trojani M, de Mascarel I, Coindre JM, Le Treut A. Metastases to the breast: differential diagnosis from primary breast carcinoma. J Surg Oncol. 1991;48:112-6.

9. Parrell Soler C, Palacios Marques A, Saco Lopez L, Bermejo De Las Heras R, Pertusa Martinez S. Breast metastatic localization of signet-ring cell gastric carcinoma ISRN. Obstet Gynecol. 2011;2011:426150.

10. Madan AK, Ternovits C, Huber SA, Pei LA, Jaffe BM. Gastrointestinal metastasis to the breast. Surgery. 2002;132:889-93.

11. Sato T, Muto I, Fushiki M, Hasegawa M, Hasegawa M, Sakai T, et al. Metastatic breast cancer from gastric and ovarian cancer, mimicking inflammatory breast cancer: report of two cases. Breast Cancer. 2008;15:315-20.

12. Boutis AL, Andreadis C, Patakiouta F, Mouratidou D. Gastric signet-ring adenocarcinoma presenting with breast metastasis. World J Gastroenterol. 2006;12:2958-61.

13. Merino MJ, Livolsi VA. Signet ring carcinoma of the female breast: a clinicopathologic analysis of 24 cases. Cancer. 1981;48:1830-7.

14. Nance FC, MacVaugh 3rd H, Fitts Jr WT. Metastatic tumor to the breast simulating bilateral primary inflammatory carcinoma. Am J Surg. 1966;112:932-5.

15. Silverman EM, Oberman HA. Metastatic neoplasms in the breast. Surg Gynecol Obstet. 1974;138:26-8.

16. Tatibana S, Asano M, Miya K, Hino T, Furuichi N, Misawa K, et al. A case report of gastric cancer with breast metastasis (Jpn). J Clin Surg. 1986;41:1719-22.

17. Alexander HR, Turnbull AD, Rosen PP. Isolated breast metastases from gastrointestinal carcinomas: report of two cases. J Surg Oncol. 1989:42:264-6.

18. Hamby LS, McGrath PC, Cibull ML, Schwartz RW. Gastric carcinoma metastatic to the breast. J Surg Oncol. 1991;48:117-21.
19. Mishina $Y$, Ohtsuka $K$, Yamamura H, Kanai T, Kitagawa $Y$, Kawai M, et al. A case or metastasis of gastric cancer to the mammary gland (in Japanese with English abstract). J J.jpn Surg Assoc. 1993;54:112-7.

20. Cavazzini G, Colpani F, Cantore M, Aitini E, Rabbi C, Taffurelli M, et al. Breast metastasis from gastric signet ring cell carcinoma, mimicking inflammatory carcinoma. A case report. Tumori. 1993;79:450-3.

21. Domanski HA. Metastases to the breast from extramammary neoplasms. A report of six cases with diagnosis by fine needle aspiration cytology. Acta Cytol. 1996;40:1293-300.

22. de la Cruz MA, Mariño CA. Breast metastases. Acta Cytol. 1998;42(5):1304-6.

23. Briest S, Horn LC, Haupt R, Schneider JP, Schneider U, Hockel M. Metastasizing signet ring cell carcinoma of the stomach-mimicking bilateral inflammatory breast cancer. Gynecol Oncol. 1999;74:491-4.

24. Kwak JY, Kim EK, Oh KK. Radiologic findings of metastatic signet ring cell carcinoma to the breast from stomach. Yonsei Med J. 2000;41:669-72.

25. Di Cosimo S, Ferretti G, Fazio N, Mandala M, Curigliano G, Bosari S, et al. Breast and ovarian metastatic localization of signet-ring cell gastric carcinoma. Ann Oncol. 2003;14:803-4.

26. Qureshi SS, Shrikhande SV, Tanuja S, Shukla PJ. Breast metastases of gastric signet ring cell carcinoma: a differential diagnosis with primary breast signet ring cell carcinoma. J Postgrad Med. 2005;51:125-7.

27. Hasegawa S, Yoshikawa T, Yoshida T, Osaragi T, Cho H, Tsuburaya A, et al. A case of breast metastasis of gastric cancer. Gan To Kagaku Ryoho. 2007;34:1115-8

28. CIT Altintaş A, Paşa S, Işikdoğan A. Gastric ring cell carcinoma metastasis to the breast: two case reports. Turk J Cancer. 2009;39:62-5.

29. Avgerinou G, Flessas I, Hatziolou E, Zografos G, Nitsios I, Zagouri F, et al. Cutaneous metastasis of signet-ring gastric adenocarcinoma to the breast with unusual clinicopathological features. Anticancer Res. 2011;31:2373-8.

30. Luk YS, Ka SY, Lo SS, Chu CY, Ma MW. An unusual case of gastric cancer presenting with breast metastasis with pleomorphic microcalcifications. J Breast Cancer. 2012;15:356-8.

\section{Submit your next manuscript to BioMed Central and take full advantage of:}

- Convenient online submission

- Thorough peer review

- No space constraints or color figure charges

- Immediate publication on acceptance

- Inclusion in PubMed, CAS, Scopus and Google Scholar

- Research which is freely available for redistribution 